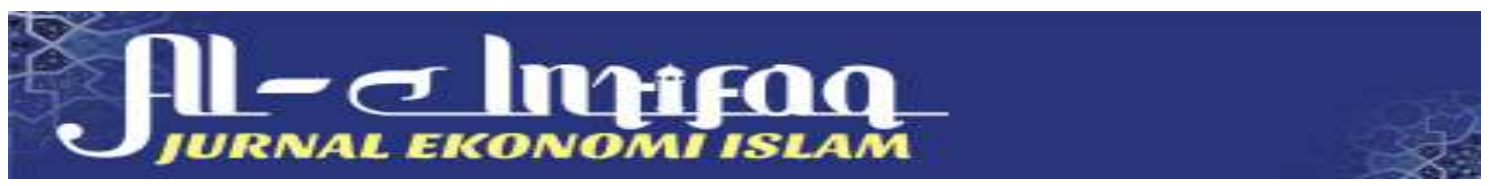

\title{
Pengaruh Variabel Ekonomi Makro Nilai Tukar Rupiah Dan Inflasi Terhadap ProfitabilitasBank Umum Syariah Di Indonesia
}

Ivo Sabrina1, Fitri Yenti², Amamil Husni ${ }^{3}$

Fakultas Ekonomi Dan Bisnis Islam, Institut Agama Islam Negeri Batusangkar ivosabrinaa@gmail.com ${ }^{1}$, fitriyenti@iainbatusangkar.ac.id ${ }^{2}$

Abstract: The purpose of this study is to explain the effect of the rupiah exchange rate on the profitability of Islamic Commercial Banks in Indonesia, to explain the effect of inflation on the profitability of Islamic Commercial Banks in Indonesia and to explain the effect of the rupiah exchange rate and inflation together on the profitability of Islamic Commercial Banks in Indonesia. The type of research that the author is doing is field research with a quantitative descriptive approach, which is a study that is intended to investigate a situation about how the effect of the rupiah exchange rate and inflation on the profitability of Islamic Commercial Banks in Indonesia. The results of this study are: the rupiah exchange rate has a positive and significant effect on the profitability of Islamic Commercial Banks in Indonesia which is shown in every increase in the rupiah exchange rate of Rp. 1, the profitability of Islamic Commercial Banks in Indonesia increases by 0.00005829. Inflation has a positive and significant impact on the profitability of Islamic Commercial Banks in Indonesia, which is indicated by every $1 \%$ increase in inflation, then the profitability of Islamic Commercial Banks in Indonesia increases by $1.1 \%$. The rupiah exchange rate and inflation together have a positive and significant effect on the profitability of Islamic Commercial Banks in Indonesia, as indicated by the value of the Fcount $>$ Ftable which is 4.629> 3.13 and the significance is $<0.05$, namely $0.000<0.05$.

Keywords: Rupiah Exchange Rate, Inflation, Profitability

Abstrak: Tujuan penelitian ini untuk menjelaskan pengaruh nilai tukar rupiah terhadap profitabilitas Bank Umum Syariah di Indonesia, menjelaskan pengaruh inflasi terhadap profitabilitas Bank Umum Syariah di Indonesia dan menjelaskan pengaruh nilai tukar rupiah dan inflasi secara bersama-sama terhadap profitabilitas Bank Umum Syariah di Indonesia. Jenis penelitian yang penulis lakukan adalah penelitian lapangan(field research)dengan pendekatan deskriptif kuantitatif, merupakan suatu penelitian yang dimaksudkan untuk menyelidiki suatu keadaan tentang bagaimana pengaruh nilai tukar rupiah dan inflasi terhadap profitabilitas Bank Umum Syariah di Indonesia. Hasil penelitian ini adalah: nilai tukar rupiah memiliki pengaruh positif dan signifikan terhadap profitabilitas Bank Umum Syariah di Indonesia yang ditunjukkan padasetiap peningkatan nilai tukar rupiah sebesar Rp.1 makaprofitabilitas Bank Umum Syariah di Indonesia meningkat sebesar o,00005829. Inflasimemiliki pengaruh positif dan signifikan terhadap profitabilitas Bank Umum Syariah di Indonesia yang ditunjukkan pada setiap peningkatan inflasi sebesar 1\%, maka profitabilitas Bank Umum Syariah di Indonesia meningkat sebesar 1,1\%. Nilai tukar rupiah dan inflasi secara bersama-samamemiliki pengaruh positif dan signifikan terhadap profitabilitas Bank Umum Syariah di Indonesia, ditunjukkan dengan nilai uji $F_{\text {hitung }}>F_{\text {tabel }}$ yaitu 4,629 > 3,13 dan signifikansinya $<0,05$ yaitu $0,000<0,05$.

Katakunci: Nilai Tukar Rupiah, Inflasi, Profitabilitas 


\section{PENDAHULUAN}

Peranan perbankan syariah secara khusus antara lain sebagai perekat nasionalisme baru, artinya menjadi fasilitator jaringan usaha ekonomi kerakyatan, memberdayakan ekonomi umat, mendorong penurunan spekulasi di pasar keuangan, mendorong pemerataan pendapatan, dan peningkatan efisiensi mobilitas dana. Bank syariah juga menjadi pemegang amanah dalam mengelola dana-dana yang dipercayakan oleh pemegang rekening investasi/deposan atas dasar prinsip bagi hasil sesuai dengan kebijakan investasi bank. (Latifah, 2016)

Berbagai indikator dalam kinerja keuangan bank pada dasarnya mencerminkan kinerja keuangan bank dalam menjalankan kegiatannya. Dalam indikator tersebut dipaparkan berbagai rasio-rasio keuangan yang mengukur seberapa besar kemampuan bank dalam mengelola keuangannya. Indikator profitabilitas biasanya dapat diukur dengan indikator ReturnOnAssets (ROA). ReturnOnAssets (ROA) penting bagi bank karena digunakan untuk mengukur efektifitas perusahaan dalam menghasilkan keuntungan dengan memanfaatkan aktiva yang dimilikinya.

Menurut (Rivai Veithzal, 2007, hal. 408) bahwa profitabilitas bank dapat dipengaruhi oleh dua faktor, yaitu faktor internal dan faktor eksternal. Faktor internal yang mempengaruhi Return On Assets (ROA) antara lain likuiditas, Biaya Operasional terhadap Pendapatan Operasional (BOPO), Capital Adequacy Ratio (CAR). Untuk faktor eksternal yang mempengaruhi tingkat Return On Assets (ROA) yaitu kondisi makroekonomi, seperti inflasi, jumlah uang beredar, suku bunga bank, Gross Domestic Product (GDP), nilai tukar, dan indikator makro ekonomi lainnya.

Inflasi adalah gejala yang menunjukkan kenaikan tingkat harga umum yang berlangsung secara terus menerus. Pada saat tingkat harga secara umum naik, pembeli harus mengeluarkan lebih banyak uang untuk jumlah barang dan jasa yang sama.

Bank syariah dalam mekanisme operasionalnya sangat jauh berbeda dengan bank konvensional, karena bank syariah punya ciri atau karakteristik tersendiri yang salah satunya bersifat mandiri. Prinsip operasional bank syariah tidak menggunakan bunga, maka secara otomatis akan terlepas dari gejolak moneter, baik dalam negeri maupun internasional. (Rizal, 2005, hal. 39)

Berdasarkan data Return on Asset (ROA) Bank Umum Syariah di Indonesia terlihat bahwa tingkat inflasi mengalami penurunan pada tahun 2014-2016. seperti yang telah dijelaskan sebelumnya bahwa bank syariah bersifat mandiri, dengan sendirinya tidak menggantungkan diri pada moneter, sehingga dapat berjalan tanpa dipengarudhi oleh inflasi. Namun pada tahun 2014-2016 Return On Asset (ROA) juga mengalami penurunan. Nilai tukar rupiah juga berpengaruh terhadap profitabilitas Bank Umum Syariah di Indonesia, walaupun telah terbukti pada saat krisis global karena faktor penguatan mata uang Dolar Amerika Serikat (USD) yang menyebabkan Bank konvensional bangkrut kemudian dibantu pemerintah melalui Bantuan Likuiditas Bank Indonesia (BLBI) senilai Rp. 650 triliun, dan Bank Syariah terbukti mampu bertahan tanpa bantuan (Rachman, 2011). Saat ini laju nilai tukar mata uang rupiah terhadap dolar Amerika Serikat terus menunjukkan pelemahannya. Nilai tukar akan mata uang asing menjadi perhatian bank karena hal itu mampu mempengaruhi tingkat profitabilitas bank. Dengan terjadinya fluktuasi akan nilai tukar mata uang asing, bank akan memperoleh pendapatan berupa fee dan selisih kurs (Hidayati, 2014, hal. 77).

Beberapa penelitian tentang Analisis Pengaruh Tingkat Suku Bunga dan Inflasi terhadap profitabilitas pada PT. Bank Syariah Mandiri Indonesia oleh Ridhwan(2016) memperlihatkan bahwa peramalan profitabilitas, suku bunga dan inflasi, dua tahun 
yang akan datang akan mengalami penurunan. Hasil uji hipotesis regresi linier berganda menunjukkan bahwa suku bunga dan inflasi secara simultan memiliki pengaruh positif dan signifikan terhadap profitabilitas (ROE) Bank Syariah Mandiri Indonesia. Bahwa variabel independen suku bunga dan inflasi hanya mampu mempengaruhi profitabilitas (ROE) Bank Syariah Mandiri Indonesia sebesar 60,8\% sedangkan sebesar 39,2\% dipengaruhi faktor lain di luar model.

Tujuan dilakukannya penelitian ini adalah untuk menjelaskan pengaruh nilai tukar rupiah, inflasi, dan nilaitukar rupiah dan inflasi bersama terhadap profitabilitas Bank Umum Syariah di Indonesia.

\section{KAJIAN TEORI}

Melihat keterkaitan antara moneter dan sektor riil atau dengan perekonomian secara makro, boleh dikatakan kebijakan moneter merupakan salah satu bagian penting dari kebijakan ekonomi makro. Kebijakan moneter, bersinergi dengan sektor lain, ditujukan untuk mendukung tercapainya target yang ingin dicapai dalam ekonomi makro. Dalam menentukan sebuah kebijakn moneter, tentunya harus ada landasan berupa dasar teori yang telah teruji atau paling tidak pengalaman yang bisa menjadi rujukan. Satu hal yang menjadi dasar teori kebijakan moneter adalah aspek penawaran dan permintaan uang. Landasan ini perlu dipahami secara rinci mengingat inti kebijakan moneter adalah mengenai pengaturan uang (Pohan, 2008, hal. 11-12).

Stabilitas dalam nilai mata uang harus menjadi tujuan utama kerangka referensi Islam karena penekanan Islam yang begitu tegas kepada kejujuran dan keadilan dalam interaksi antarmanusia. Al-Quran dengan tegas menekankan kejujuran dan keadilan dalam semua ukuran nilai.

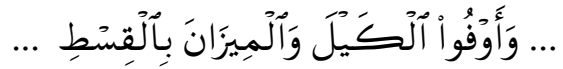

$$
\begin{aligned}
& \text { “...dan sempurnakanlah takaran dan timbangan dengan adil..." (al-An'am:152) }
\end{aligned}
$$

Menurut Keynes, permintaan uang selain dipengaruhi oleh motif transaksi juga dipengaruhi oleh motif spekulasi. Dalam melakukan transaksi surat-surat berharga khususnya obligasi, untuk memperoleh keuntungan pembelian obligasi dilakukan pada waktu harga obligasi murah dan penjualan dilakukan pada waktu obligasi mahal.

Perubahan harga obligasi juga mempengaruhi tingkat suku bunga obligasi. Kenaikan harga obligasi berarti persentase suku bunga menurun dan sebaliknya penurunan harga obligasi berarti persentase suku bunga meningkat. Milton Friedman mengembangkan teori permintaan uang dengan menggunakan pendekatan teori ekonomi mikro, yaitu dengan melihat tingkah laku konsumen dan produsen dalam memenuhi kebutuhannya. Menurut Friedman, konsumen memegang uang karena uang dapat memberikan kegunaan (utility), yaitu berupa kemudahan untuk melakukan pembayaran atas transaksi yang dilakukan (Pohan, 2008, hal. 14)

Bank adalah badan usaha yang menghimpun dana dari masyarakat dalam bentuk simpanan, dan menyalurkannya kepada masyarakat dalam rangka meningkatkan taraf hidup rakyat banyak. (Pohan, 2008, hal. 85)

Inflasi dianggap sebagai fenomena moneter, karena terjadinya penurunan nilai unit perhitungan moneter terhadap suatu komoditas. Inflasi adalah gejala yang menunjukkan kenaikan tingkat harga umum yang berlangsung terus-menerus. Kenaikan harga tersebut dimaksudkan bukan terjadi sesaat. (Rozalinda, 2014, hal. 298) 
Inflasi mengandung implikasi bahwa uang tidak dapat berfungsi sebagai satuan hitung yang adil dan benar. Inflasi berakibat buruk pada perekonomian karena menimbulkan gangguan terhadap fungsi uang. Hal itu menyebabkan uang menjadi pembayaran tertunda yang tidak adil dan alat penyimpan kekayaan yang tidak dapat dipercaya. Inflasi menyebabkan orang berlaku tidak adil terhadap orang lain meskipun tidak disadarinya dengan merosotnya daya beli aset-aset moneter secara tidak diketahui.

Nilai tukar (exchange rate) atau kurs adalah harga relatif mata uang suatu negara terhadap mata uang negara lain. Terdapat dua cara untuk menyatakan kurs (Abimanyu, 2004, hal. 6-7), yaitu:

1. Model Eropa yang sering disebut dengan Indirect Quote.

2. Model Amerika yang sering disebut Direct Quote.

Secara umum, terdapat dua macam kurs, yaitu kurs beli (bid) dan kurs jual (offer). Kurs beli adalah harga di mana dealer yang terdiri dari bank dan money changer bersedia membeli mata uang asing. Kurs jual adalah harga di mana dealer bersedia menjual mata uang asing. Selisih kurs jual dan kurs beli merupakan keuntungan bagi dealer tersebut (Abimanyu, 2004, hal. 7)

Perubahan kurs valuta asing terdapat beberapa macam yaitu devaluasi, revaluasi, depresiasi, dan apresiasi. Perubahan ini dapat disebabkan oleh mekanisme penawaran dan permintaan di pasar, maupun disebabkan oleh kebijakan pemerintah.

Pengelolaan nilai tukar yang realistis dan perubahan yang cukup rendah dapat memberikan kepastian dunia usaha sebagaimana yang terjadi pada beberapa waktu terakhir merupakan suatu hal yang penting dalam peningkatan investasi maupun kegiatan yang berorientasi pada ekspor. Nilai tukar yang melonjak-lonjak secara drastis tak terkendali aka menyebabkan kesulitan pada dunia usaha dalam merencanakan usahanya terutama bagi mereka yang mendatangkan bahan baku dari luar negeri atau menjual barangnya ke pasar ekspor. (Pohan, 2008, hal. 55).

Bank Islam atau di Indonesia disebut bank syariah merupakan lembaga keuangan yang berfungsi memperlancar mekanisme ekonomi sektor riil melalui aktivitas kegiatan usaha (investasi, jual beli, atau lainnya) berdasarkan prinsip syariah, yaitu aturan perjanjian berdasarkan hukum Islam antara bank dan pihak lain untuk penyimpanan dana atau pembiyaan kegiatan usaha, atau kegiatan lainnya yang dinyatakan sesuai dengan nilai-nilai syariah yang bersifat makro atau mikro (Ascarya, 2011, hal. 30).

Menurut Karnaen A. Perwata Atmadja dan Syafi'i Antonio, bank syariah memiliki dua pengertian yaitu:

1. Bank yang beroperasi sesuai dengan asas-asas syariah Islam Bank yang beroperasi mengikuti aturan dan tata cara yang ada pada al-Quran dan hadist

2. Bank Umum Syariah (BUS) adalah bank syariah yang kegiatannya memberikan jasa dalam lalu lintas pembayaran. BPRS adalah bank syariah yang dalam melaksanakan kegiatan usahanya tidak memberikan jasa dalam lalu lintas pembayaran.

Tujuan utama bank syariah ialah mendorong dan mempercepat kemajuan ekonomi suatu masyarakat atau bangsa, dengan melakukan aktivitas perbankan, keuangan, komersial, dan investasi sesuai dengan asas Islam. Upaya ini harus didasari (Iska, 2012, hal. 51), dengan:

1. Larangan atas bunga pada setiap transaksi

2. Asas kerekanan (partnership) pada semua aktivita bisnis yang berdasarkan kesetaraan 
3. Hanya mencari keuntungan yang sah dan halal semata-mata

4. Pembiayaan manajemen keuangan kepada masyarakat

5. Mengembangan persaingan yang sehat

6. Menghidupkan lembaga zakat

7. Dan pembentukan jaringan kerja sama dengan lembaga keuangan Islam lainnya.

Rasio profitabilitas merupakan rasio untuk menilai kemampuan bank dalam mencari keuntungan. Rasio ini juga memberikan ukuran tingkat efektifitas manajemen suatu perusahaan. Laba terdiri dari laba kotor, laba operasi, dan laba bersih. Untuk memperoleh laba di atas rata-rata, manajemen harus mampu meningkatkan pendapatan (revenue) dan mengurangi semua beban (expensses) atas pendapatan. Itu berarti manajemen baru memperluas pangsa pasar dengan tingkat harga menguntungkan dan menghapuskan aktivitas yang tidak bernilai tambah (Prawironegoro, 2014, hal. 55).

Penggunaan rasio profitabilitas dapat dilakukan dengan menggunakan perbandingan antara berbagai komponen yang ada di laporan keuangan, terutama di laporan keuangan neraca dan laba rugi.

\section{METODE PENELITIAN}

Jenis Penelitian

Jenis penelitian ini adalah penelitian lapangan (field research) dengan pendekatan kuantitatif yaitu menggunakan instrumen untuk mengumpulkan data atau mengukur suatu variabel yang diteliti (Sugiyono, 2012, hal. 2). Deskriptif adalah metode yang dilakukan dengan mengumpulkan, mengklasifikasi, menganalisis, serta menginterprestasikan data sehingga memberikan keterangan yang lengkap bagi pemecahan masalah yang terjadi (Husein, 2010, hal. 3).

Metode penelitian yang penulis lakukan adalah deskriptif kuantitatif yaitu dengan mengolah data-data yang penulis dapatkan pada laporan keuangan untuk memberikan hasil analisis.

\section{Teknik Analisis Data}

Untuk penganalisisan penelitian ini, penulis menganalisa secara kuantitatif yaitu dengan melihat nilai tukar rupiah atau kurs dan inflasi, kemudian menghubungkannya dengan profitabilitas Bank Umum Syariah di Indonesia. Penulis menjelaskan bahwa variabel $X_{1}$ (nilai tukar rupiah), dan $X_{2}$ (inflasi) merupakan independent atau variabel yang mempengaruhi dan variabel $Y$ merupakan variabel dependent (Profitabilitas Bank Umum Syariah di Indonesia) atau variabel yang dipengaruhi.

1. Statistik Deskriptif

Metode analisis statistik deskriptif menurut (Sugiyono, 2012, hal. 147) digunakan untuk menganalisis data dengan cara mendeskripsikan atau menggambarkan data yang telah terkumpul sebagaimana adanya tanpa maksud membuat kesimpulan yang berlaku untuk umum atau generalisasi.

Statistik deskriptif keseluruhan variabel penelitian yang mencakup nilai minimum, maksimum, dan rata-rata, seperti terlihat pada tabel di bawah ini:

Tabel 1

Statistik Deskriptif 
Nilai Tukar Rupiah, Inflasi dan Return On Aset (ROA)

Tahun 2012-2017

\begin{tabular}{|l|l|l|l|}
\hline & Minimum & Maksimum & Rata-Rata \\
\hline Nilai Tukar Rupiah & Rp. 8.981,- & Rp. 14.472,- & Rp. 11.962,- \\
\hline Inflasi & $2,79 \%$ & $8,79 \%$ & $1,74 \%$ \\
\hline ROA & $1,77 \%$ & $2,81 \%$ & $2,22 \%$ \\
\hline
\end{tabular}

2. Uji Normalitas

Untuk uji normalitas data, penulis menggunakan uji KormogorovSmirnov dengan taraf signifikan 0,05 (5\%). Apabila signifikasinya lebih dari 0,05 maka dapat disimpulkan bahwa data terdistribusi secara normal (Priyatno, 2009, hal. 187).

3. Metode Korelasi Berganda

Dalam korelasi dikenal dengan penyebab dan akibat, data penyebab atau yang mempengaruhi disebut variabel bebas data akibat atau yang dipengaruhi disebut varibel terikat.

Untuk melihat hubungan variabel $\mathrm{X}_{1}, \mathrm{X}_{2}$ dalam hal ini nilai tukar rupiah dan inflasi terhadap variabel Y yaitu profitabilitas Bank Umum Syariah di Indonesia, digunakan koefisien korelasi (r) dengan rumus Korelasi Berganda yaitu (Sugiyono, 2012, hal. 58):

$$
\mathrm{r}_{\mathrm{y}} \cdot \mathrm{x}_{1} \mathrm{x}_{2}=\sqrt{\frac{r^{2} y x_{1}+r^{2} y x_{\mathrm{z}}-2 r_{y x_{1}} r_{y x_{2}} r_{x_{1} x_{2}}}{1-r^{2} x_{12 x}}}
$$

Dimana:

$\mathrm{y} \cdot 1 \mathrm{x}_{2}=\quad$ Korelasi ganda variabel $\mathrm{X}_{1}$ dengan $\mathrm{X}_{2}$ secara bersamasama dengan $Y$

$\operatorname{ryx}_{1} \quad=\quad$ Korelasi sederhana antara $X_{1}$ dengan $Y$

$\operatorname{ryx}_{2} \quad=\quad$ Korelasi sederhana antara $X_{2}$ dengan $Y$

$\mathrm{rx}_{1} \mathrm{x}_{2}=$ Korelasi sederhana antara $\mathrm{X}_{1}$ dengan $\mathrm{X}_{2}$

Hasil dari korelasi berganda akan diperoleh koefisien korelasi dimana akan diperoleh kemungkinan nilai korelasi bergerak antara -1 sampai dengan +1 dengan kriteria Interprestasi koefisien korelasi (r) tersebut sebagai berikut menurut (Singion) dalam Skripsi (Putra, 2013):

Jika hasil korelasi 0, maka kedua pihak variabel tidak berkorelasi

Jika hasil korelasi 0,01-0,09, maka korelasi sangat lemah

Jika hasil korelasi 0,10-0,499, maka korelasi lemah

Jika hasil korelasi 0,50-0,799, maka korelasi sedang

Jika hasil korelasi 0,80-0,999, maka hasil korelasi kuat

Jika hasil korelasi 1, maka korelasi sangat kuat (sempurna)

Jika hasil korelasi -1, maka korelasi sangat kuat negatif (kebalikan)

4. Uji Hipotesis
a. Analisis Determinasi $\left(\mathrm{R}^{2}\right)$
Dalam hal ini penulis ingin melihat seberapa besar pengaruh nilai tukar rupiah atau kurs dan inflasi terhadap profitabilitas Bank Umum Syariah di Indonesia.
b. Ujit
Untuk Uji $t$, penelitian ini membandingkan antara $t$ hitung dengan $t$ tabel dengan taraf signifikansi 0,05 (5\%). Apabila $\mathrm{t}$ hitung lebih besar dari $\mathrm{t}$ 
tabel, maka dapat disimpulkan bahwa masing-masing variabel independen secara individual berpengaruh terhadap variabel dependen.

c. Uji F

Uji F digunakan untuk mengetahui pengaruh semua variabel independennya yang dimaksudkan dalam model regresi secara bersamasama terhadap variabel dependen yang diuji pada tingkat signifikan 0,055\%), maka dapat disimpulkan bahwa semua variabel independen yang diteliti secara bersama-sama mempengaruhi variabel dependen.

5. Metode Regresi Linier Berganda

Analisis regresi linier berganda digunakan untuk memperkirakan atau menghitung nilai variabel $X_{1}$ (nilai tukar rupiah), $X_{2}$ (inflasi) yang menyebabkan perubahan variabel Y (Profitabilitas Bank Umum Syariah di Indonesia) dan melihat seberapa besar pengaruh variabel $X_{1}$ dan $X_{2}$ terhadap variabel $\mathrm{Y}$, dengan persamaan regresi linier berganda, dengan rumus (menurut Husman dan Suarsono Muhammad (Studi Kelayakan Proyek) dalam (Putra, 2013, hal. 63)):

$\mathrm{Y}=\mathrm{a}+\mathrm{b}_{1} \mathrm{x}_{1}+\mathrm{b}_{2} \mathrm{x}_{2}+\mathrm{e}$

Dimana:

Y = Profitabilitas Bank Umum Syariah di Indonesia (Dependent)

$\mathrm{x}_{1}=$ Nilai tukar rupiah (Independent)

$\mathrm{x}_{2} \quad=$ Inflasi (Independent)

a $\quad$ Konstanta

$\mathrm{b}_{1}, \mathrm{~b}_{2}=$ Koefisien arah regresi

$\mathrm{e} \quad=$ error

\section{HASIL DAN PEMBAHASAN}

\section{Hasil Analisis}

1. Staistik deskriptif

Tabel 2

Descriptive Statistics

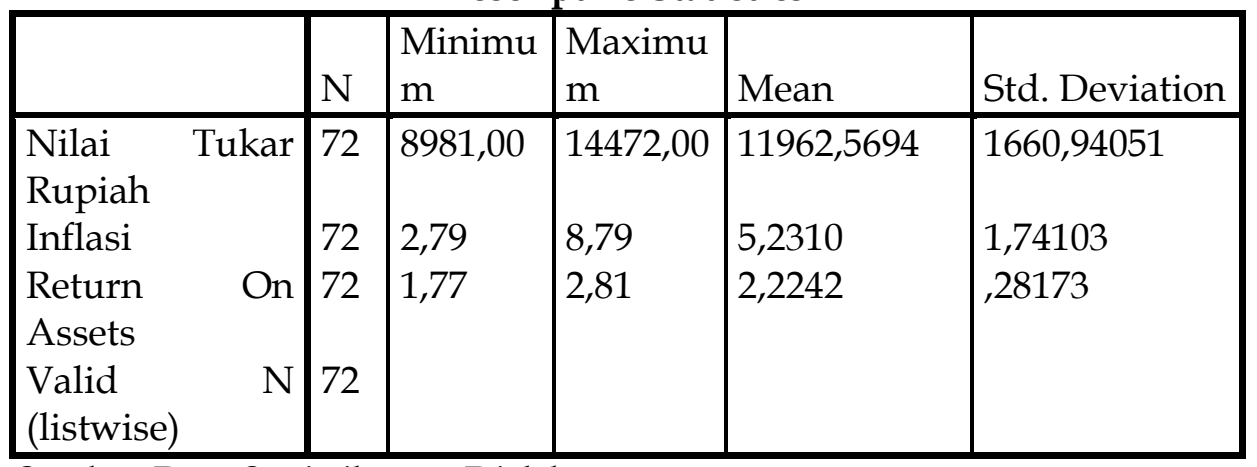

Sumber: Data Statistik yang Diolah

Dari tabel dijelaskan bahwa jumlah data $(\mathrm{N})$ yang diuji sebanyak 72 . Selain itu diperoleh gambaran nilai minimum, maksimum, nilai rata-rata serta standar deviasi masing-masing variabel adalah sebagai berikut:

a. Nilai Tukar Rupiah

Dari hasil statistik deskriptif diketahui bahwa nilai tukar rupiah terkecil yaitu Rp. 8981,00 pada bulan Februari 2012. Nilai tukar rupiah terbesar yaitu Rp. 14472,00 pada bulan September 2015. Rata-rata nilai tukar rupiah yaitu Rp. 11962,00 dengan standar deviasi sebesar Rp. 1661,00. 
b. Inflasi

Dari hasil statistik deskriptif diketahui bahwa tingkat inflasi terkecil yaitu 2,79\% pada bulan Agustus 2016. Tingkat inflasi terbesar yaitu 8,79\% pada bulan Agustus 2013. Rata-rata tingkat inflasi yaitu 5,23\% dengan standar deviasi 1,74\%.

c. Return On Asset (ROA)

Dari hasil statistik deskriptif diketahui bahwa Return On Asset (ROA) terkecil yaitu 1,77\%. Return On Asset terbesar yaitu 2,81\%. Rata-rata Return On Asset (ROA) yaitu 2,22\% dengan standar deviasi yaitu 0,28\%.

2. Uji Normalitas

Tabel 3

One-Sample Kolmogorov-Smirnov Test

\begin{tabular}{|ll|l|}
\hline & & Unstandardized Residual \\
\hline $\mathrm{N}$ & & 72 \\
Normal Parametersa,b & Mean &, 0000000 \\
& Std. Deviation &, 26454612 \\
Most Extreme & Absolute &, 099 \\
Differences & Positive &, 099 \\
& Negative &,- 058 \\
Kolmogorov-Smirnov Z &, 838 \\
Asymp. Sig. (2-tailed) &, 484 \\
\hline
\end{tabular}

a. Test distribution is Normal.

Sumber: Data Statistik yang Diolah

Dari output di atas dapat dilihat bahwa jumlah data $(\mathrm{N})$ adalah 72; ratarata 0,0000000; standar deviasi 0,26454612; absolut 0,099; differences postive 0,099; negatif -0,058; Kolmogorof-Smirnov $Z$ adalah 0,838 dan signifikansi 0,484 . Karena signifikansi 0,484 >0,05 jadi dapat disimpulkan bahwa perubahan nilai tukar rupiah dan inflasi dikatakan normal.

3. Analisis korelasi berganda

Tabel 4

Uji Korelasi Berganda

Model Summaryb

\begin{tabular}{|l|l|l|l|l|}
\hline Model & $\mathrm{R}$ & R Square & $\begin{array}{l}\text { Adjusted } \\
\text { Square }\end{array}$ & $\begin{array}{l}\text { Std. Error of the } \\
\text { Estimate }\end{array}$ \\
\hline 1 &, $344^{\mathrm{a}}$ &, 118 &, 093 &, 26835 \\
\hline
\end{tabular}

a. predictors: (Constant), Inflasi, Nilai Tukar Rupiah

b. Dependen Variabel: Return On Assets

Sumber: Data Statistik yang Diolah

Berdasarkan tabel diatas diperoleh koefisien korelasi antara nilai tukar rupiah dan inflasi dengan nilai $r=0,344$. Setelah dilakukan perbandingan dengan berpedoman pada kriteria interpretasi koefisien korelasi nilai yang 
ditemukan sebesar 0,344 (berada diantara 0,10-0,499), sehingga menunjukkan adanya hubungan antara variabel $\mathrm{X}_{1}, \mathrm{X}_{2}$, terhadap $\mathrm{Y}$ yang lemah. Hal ini sesuai dengan interpretasi korelasi.

4. Uji Hipotesis

a. Analisis Determinasi

Tabel 5

Uji Determinasi

Model Summaryb

\begin{tabular}{|l|l|l|l|l|}
\hline Model & $\mathrm{R}$ & $\begin{array}{l}\mathrm{R} \\
\text { Square }\end{array}$ & $\begin{array}{l}\text { Adjusted } \mathrm{R} \\
\text { Square }\end{array}$ & $\begin{array}{l}\text { Std. Error of the } \\
\text { Estimate }\end{array}$ \\
\hline 1 &, $344^{\mathrm{a}}$ &, 118 &, 093 &, 26835 \\
\hline
\end{tabular}

a. predictors: (Constant), Inflasi, Nilai Tukar Rupiah

Sumber: Data Statistik yang Diolah

Data dari tabel di atas dapat diperoleh $\mathrm{R}$ Square $\left(\mathrm{R}^{2}\right)$ sebesar 0,118. Hal ini berarti varian yang terjadi pada variabel Return On Asset (ROA) Bank Umum Syariah di Indonesia 11,8\% dapat dijelaskan oleh varian yang terjadi pada variabel nilai tukar rupiah dan inflasi.

Uji $t$

Hasil Uji t dapat dilihat pada tabel berikut:

Tabel 6

Uji t

\begin{tabular}{|c|c|c|c|c|c|c|}
\hline \multirow{2}{*}{\multicolumn{2}{|c|}{ Model }} & \multicolumn{2}{|c|}{$\begin{array}{l}\text { Unstandardized } \\
\text { Coefficients }\end{array}$} & \multirow{2}{*}{$\begin{array}{l}\text { Standardize } \\
\text { d } \\
\text { Coefficients } \\
\text { Beta }\end{array}$} & \multirow[b]{2}{*}{$\mathrm{t}$} & \multirow[b]{2}{*}{ Sig. } \\
\hline & & B & $\begin{array}{l}\text { Std. } \\
\text { Error }\end{array}$ & & & \\
\hline 1 & (Constant) & 1,468 & ,260 & & 5,641 & , 000 \\
\hline & $\begin{array}{ll}\text { Nilai } & \text { Tukar } \\
\text { Rupiah } & \end{array}$ & $5,829 \mathrm{E}-5$ & ,000 & ,344 & 3,025 & ,003 \\
\hline & Inflasi & ,011 & ,018 & ,070 & 2,617 & ,001 \\
\hline
\end{tabular}

a. Dependent Variable: Return On Assets

Sumber: Data Statistik yang Diolah

Uji t dilakukan untuk menyelidiki lebih lanjut mana diantara variabel independen yang berpengaruh terhadap Return On Asset (ROA). Uji $t$ dilakukan dengan membandingkan $\mathrm{t}$ hitung dengan $\mathrm{t}$ tabel, taraf signifikansi $5 \%: 2=2,5 \%$ (uji 2 sisi) dengan derajat kebebasan $(\mathrm{df})=\mathrm{n}-\mathrm{k}$ atau $72-2=70(\mathrm{n}$ adalah jumlah sampel dan $\mathrm{k}$ adalah jumlah variabel independen). Dengan pengujian 2 sisi (signifikan $=0,025)$, maka hasil yang diperoleh untuk $t$ tabel sebesar 1,994.

Sehingga didapat hasil pengujian sebagai berikut:

I. Hipotesis 1 
Dengan hipotesis statistik pertama yang akan diuji sebagai berikut: $\mathrm{H}_{01}$ : Nilai tukar rupiah tidak berpengaruh terhadap profitabilitas Bank Umum Syariah di Indonesia

$\mathrm{Ha}_{1}$ : Nilai tukar rupiah berpengaruh terhadap profitabilitas Bank Umum Syariah di Indonesia

Variabel nilai tukar rupiah memiliki t hitung sebesar 3,025 dengan taraf signifikan 0,003 dibawah signifikan 0,05 (5\%). Dengan demikian $\mathrm{t}$ hitung $>\mathrm{t}$ tabel $(3,025>1,994)$. Maka $\mathrm{H}_{01}$ ditolak dan $\mathrm{Ha}_{1}$ diterima, sehingga dapat dinyatakan $\mathrm{H}_{01}$ yang menyatakan "Nilai tukar rupiah tidak berpengaruh terhadap profitabilitas Bank Umum Syariah di Indonesia" ditolak, dan hipotesis alternatif diterima. Jadi dapat disimpulkan bahwa "nilai tukar rupiah berpengaruh signifikan terhadap profitabilitas Bank Umum Syariah di Indonesia".

II. Hipotesis 2

Dengan hipotesis statistik kedua akan diuji sebagai berikut:

$\mathrm{H}_{02}$ : Inflasi tidak berpengaruh terhadap profitabilitas Bank Umum Syariah di Indonesia

$\mathrm{Ha}_{2}$ : Inflasi berpengaruh terhadap profitabilitas Bank Umum Syariah di Indonesia

Variabel inflasi memiliki t hitung 2,617 dengan taraf signifikan 0,001 di bawah signifikan 0,05\% (5\%). Dengan demikian $\mathrm{t}$ hitung $>\mathrm{t}$ tabel $(2,617>$ 1,994). Maka $\mathrm{H}_{02}$ ditolak dan $\mathrm{Ha}_{2}$ diterima. Sehingga dapat dinyatakan $\mathrm{H}_{02}$ yang menyatakan "Inflasi tidak berpengaruh terhadap profitabilitas Bank Umum Syariah di Indonesia" ditolak, dan hipotesis alternatif diterima. Jadi dapat disimpulkan bahwa "inflasi berpengaruh terhadap profitabilitas Bank Umum Syariah di Indonesia".

Uji F

\section{Tabel 7}

Uji F

ANOVA $^{b}$

\begin{tabular}{|ll|l|l|l|l|l|}
\hline Model & $\begin{array}{l}\text { Sum } \\
\text { Squares }\end{array}$ & of & Mean Square & F & Sig. \\
\hline 1 & $\begin{array}{l}\text { Regressio } \\
\mathrm{n}\end{array}$ &, 667 & 2 &, 333 & 4,629 &, $000^{\mathrm{a}}$ \\
& & & & & \\
& Residual & 4,969 & 69 &, 072 & & \\
\hline
\end{tabular}

a. Predictors: (Constant), Inflasi, Nilai Tukar Rupiah

b. Dependent Variable: Return On Assets

Sumber: Data Statistik yang Diolah

Dalam hal ini peran ANOVA adalah untuk menguji signifikansi pengaruh nilai tukar rupiah da inflasi secara besama-sama terhadap profitabilitas Bank Umum Syariah di Indonesia, pengujian menggunakan tingkat signifikansi 0,05.

Dari output diperoleh $\mathrm{F}$ hitung sebesar 4,629 dan tingkat signifikansi 0,000. F tabel dapat dilihat pada tabel statistik pada tingkat signifikansi 0,05 dengan df 1 (jumlah variabel -1 ) atau $3-1=2$, dan df $2(n-k)$ atau $72-2=70$ 
(n adalah jumlah data dan $\mathrm{k}$ adalah jumlah variabel independen). Hasil yang diperoleh untuk $\mathrm{F}$ tabel adalah sebesar 3,13.

III. Hipotesis 3

Dengan hipotesis statistik ketiga yang akan diuji sebagai berikut:

$\mathrm{H}_{03}$ :Nilai tukar rupiah dan inflasi secara bersama-sama tidak berpengaruh terhadap profitabilitas Bank Umum Syariah di Indonesia

Ha3: Nilai tukar rupiah dan inflasi secara bersama-sama berpengaruh terhadap profitabilitas Bank Umum Syariah di Indonesia

Karena nilai $\mathrm{F}$ hitung $>\mathrm{F}$ tabel $(4,629>3,13)$ dan signifikansi $<0,05(0,000$ $<0,05)$, maka hasil ini membuktikan bahwa $\mathrm{H}_{03}$ ditolak dan $\mathrm{Ha}_{3}$ diterima, sehingga dapat dinyatakan $\mathrm{H}_{03}$ yang menyatakan "Nilai tukar rupiah dan inflasi secara bersama-sama tidak berpengaruh terhadap profitabilitas Bank Umum Syariah di Indonesia" ditolak, dan hipotesis alternatif diterima. Jadi, kesimpulannya "Nilai tukar rupiah dan inflasi secara bersama-sama memiliki pengaruh yang signifikan terhadap profitabilitas Bank Umum Syariah".

a. Analisis Regresi Linier Berganda

Bentuk umum persamaan regresi linier berganda yang digunakan adalah sebagai berikut:

$\mathrm{Y}=\mathrm{a}+\mathrm{b}_{1} \mathrm{x}_{1}+\mathrm{b}_{2} \mathrm{x}_{2}$

Dimana: $\quad Y=$ Profitabilitas Bank Umum Syariah di Indonesia (Dependen)

$\mathrm{X}_{1}=$ Nilai tukar rupiah (Independen)

$\mathrm{X}_{2}=$ Inflasi (Independen)

$\mathrm{a}=$ Konstanta

$b_{1} b_{2}=$ Koefisien arah regresi

Berdasarkan persamaan regresi diatas, maka peneliti mendapatkan hasil penelitian sebagai berikut:

Analisis Regresi Linier Berganda

Coefficients ${ }^{a}$

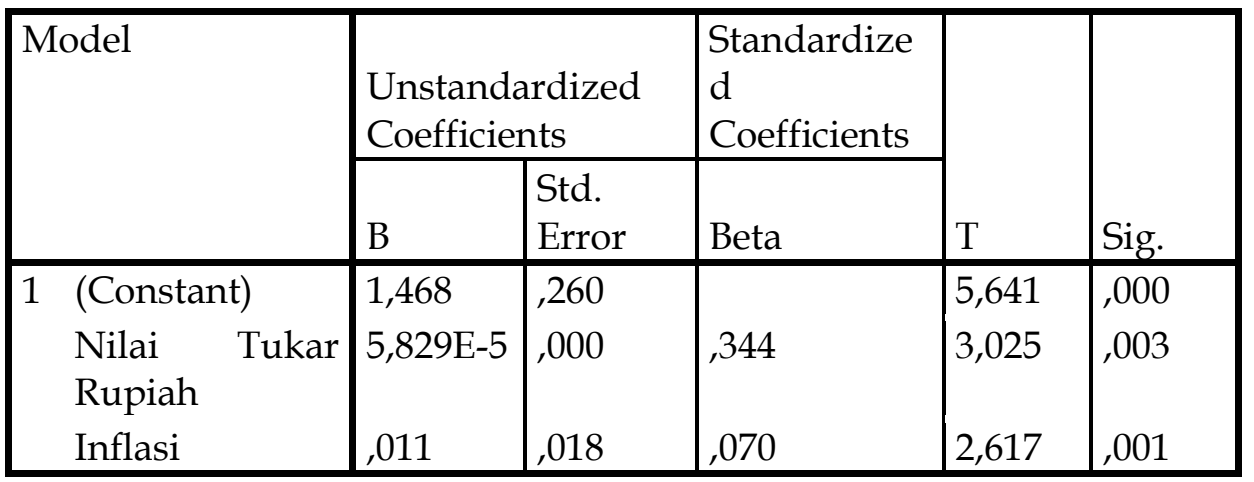

a. Dependent Variable: Return On Assets

Sumber: Data Statistik yang Diolah

Dari nilai-nilai koefisien diatas, dapat disusun persamaan regresi linier sebagai berikut:

Dimana:

$$
\mathrm{Y}=1,468+0,00005829 \mathrm{X}_{1}+0,011 \mathrm{X}_{2}
$$

$\mathrm{a}=$ nilai konstanta di atas adalah sebesar 1,468. Artinya bahwa jika variabel independen yaitu nilai tukar rupiah $\left(X_{1}\right)$ dan inflasi $\left(X_{2}\right)$ bernilai nol $(0)$, maka besarnya profitabilitas pada Bank Umum Syariah di Indonesia 
adalah sebesar $1,468 \% \mathrm{~b}_{1}=$ Variabel nilai tukar rupiah memiliki koefisien regresi bernilai positif yaitu sebesar 0,00005829, ini dapat diartikan bahwa setiap peningkatan nilai tukar rupiah sebesar Rp.1 maka profitabilitas Bank Umum Syariah di Indonesia meningkat sebesar 0,00005829.

$b_{2}=$ Variabel Inflasi memiliki koefisien regresi bersifat positif yaitu 0,011 atau $1,1 \%$, ini dapat diartikan bahwa setiap peningkatan inflasi sebesar 1\%, maka profitabilitas Bank Umum Syariah di Indonesia meningkat sebesar $1,1 \%$.

\section{Perbandingan Pengaruh Nilai Tukar Rupiah dan Inflasi terhadap Profitabilitas Bank Umum Syariah di Indonesia}

1. Berdasarkan analisis korelasi berganda

Diperoleh hasil $r=0,344$ menunjukkan terdapat hubungan atau korelasi yang lemah antara nilai tukar rupiah dan inflasi terhadap profitabilitas Bank Umum Syariah di Indonesia karena $r=0,344$ berada diantara 0,10 - 0,499.

1. Berdasarkan Uji Hipotesis

a. Uji Determinasi $\left(R^{2}\right)$

Diperoleh R Square $\left(\mathrm{R}^{2}\right)$ sebesar 0,118 , ini artinya bahwa nilai tukar rupiah dan inflasi memiliki pengaruh terhadap profitabilitas Bank Umum Syariah di Indonesia sebesar 11,8\% dan sisanya 88,2\% dijelaskan oleh faktor lain yang tidak dimasukkan ke dalam penelitian ini. Hal ini menunjukkan bahwa nilai tukar rupiah dan inflasi merupakan faktor yang memiliki pengaruh terhadap profitabilitas Bank Umum Syariah di Indonesia.

b. Uji t

Variabel nilai tukar rupiah memiliki t hitung sebesar 3,025 dengan taraf signifikan 0,003 dibawah signifikan 0,05 (5\%). Dengan demikian $\mathrm{t}$ hitung $>\mathrm{t}$ tabel $(3,025>1,994)$. Maka $\mathrm{H}_{01}$ ditolak dan $\mathrm{Ha}_{1}$ diterima. $\mathrm{Ha}_{1}$ yang menyatakan "Nilai tukar rupiah berpengaruh terhadap profitabilitas Bank Umum Syariah di Indonesia".

Variabel inflasi memiliki t hitung 2,617 dengan taraf signifikan 0,001 dibawah signifikan 0,05 (5\%). Dengan demikian $t$ hitung $>t$ tabel $(2,617>$ 1,994). Maka $\mathrm{H}_{02}$ ditolak dan $\mathrm{Ha}_{2}$ diterima. $\mathrm{Ha}_{2}$ yang menyatakan "Inflasi berpengaruh terhadap profitabilitas Bank Umum Syariah di Indonesia" c. Uji F

Karena nilai $\mathrm{F}$ hitung $>\mathrm{F}$ tabel $(4,629>3,13)$ dan signifikansi $<0,05$ $(0,000<0,05)$, maka hasil ini membuktikan bahwa $\mathrm{H}_{03}$ ditolak dan $\mathrm{Ha}_{3}$ diterima. $\mathrm{Ha}_{3}$ yang menyatakan "Nilai tukar rupiah dan inflasi secara bersama-sama berpengaruh terhadap profitabilitas Bank Umum Syariah di Indonesia"

2. Berdasarkan Analisis Regresi Linier Berganda

Berdasarkan dari hasil nilai-nilai koefisien yang diperoleh, dapat disusun persamaan regresi sebagai berikut:

$$
\mathrm{Y}=1,468+0,00005829 \mathrm{X}_{1}+0,011 \mathrm{X}_{2}
$$

Dimana:

$\mathrm{a}=$ nilai konstanta diatas adalah sebesar 1,468. Artinya bahwa jika variabel independen yaitu nilai tukar rupiah $\left(X_{1}\right)$ dan inflasi $\left(X_{2}\right)$ bernilai nol $(0)$, maka besarnya profitabilitas pada Bank Umum Syariah di Indonesia 
adalah sebesar $1,468 \% b_{1}=$ Variabel nilai tukar rupiah memiliki koefisien regresi bernilai positif yaitu sebesar 0,00005829, ini dapat diartikan bahwa setiap peningkatan nilai tukar rupiah sebesar Rp.1 maka profitabilitas Bank Umum Syariah di Indonesia meningkat sebesar 0,00005829.

$b_{2}=$ Variabel Inflasi memiliki koefisien regresi bersifat positif yaitu 0,011 atau $1,1 \%$, ini dapat diartikan bahwa setiap peningkatan inflasi sebesar 1\%, maka profitabilitas Bank Umum Syariah di Indonesia meningkat sebesar $1,1 \%$.

\section{KESIMPULAN DAN KONTRIBUSI PENELITIAN}

\section{Kesimpulan}

1. Nilai Tukar Rupiah Memiliki Pengaruh yang Signifikan terhadap Profitabilitas Bank Umum Syariah di Indonesia

Variabel nilai tukar rupiah memiliki t hitung sebesar 3,025 dengan taraf signifikan 0,003 dibawah signifikan 0,05 (5\%). Dengan demikian t hitung > dari $\mathrm{t}$ tabel $(3,025>1,994)$. Maka $\mathrm{H}_{01}$ ditolak dan $\mathrm{Ha}_{2}$ diterima. Jadi, dapat disimpulkan bahwa nilai tukar rupiah berpengaruh positif dan signifikan terhadap profitabilitas Bank Umum Syariah di indonesia yang ditunjukkan dengan nilai signifikan 0,003 atau 3\%. maksudnya jika nilai tukar rupiah menguat maka profitabilitas Bank Umum Syariah di Indonesia akan naik, dan sebaliknya jika nilai tukar rupiah melemah maka profitabilitas Bank Umum Syariah di Indonesia akan turun.

2. Inflasi Memiliki Pengaruh terhadap Profitabilitas Bank Umum Syariah di Indonesia

Variabel Inflasi memiliki t hitung sebesar 2,617 dengan taraf signifikan 0,001 dibawah signifikan 0,05 (5\%). Dengan demikian $t$ hitung $>t$ tabel $(2,617$ $<1,994)$. Maka $\mathrm{H}_{02}$ ditolak dan $\mathrm{Ha}_{2}$ diterima. Jadi, dapat disimpulkan bahwa Inflasi berpengaruh positif dan signifikan terhadap profitabilitas Bank Umum Syariah di Indonesia yang ditunjukkan dengan nilai signifikan 0,001 atau 1\%. Maksudnya, jika tingkat inflasi naik, maka profitabilitas Bank Umum Syariah di Indonesia akan turun, dan sebaliknya jika tingkat inflasi turun maka profitabilitas Bank Umum Syariah di Indonesia akan naik.

3. Nilai Tukar Rupiah dan Inflasi Secara Bersama Memiliki Pengaruh terhadap Profitabilitas Bank Umum Syariah di Indonesia

Karena nilai $\mathrm{F}$ hitung $>\mathrm{F}$ tabel $(4,629>3,13)$ dan signifikansi $<0,05$ $(0,000<0,05)$, maka hasil ini membuktikan bahwa $\mathrm{H}_{03}$ ditolak dan $\mathrm{Ha}_{3}$ diterima. Jadi, kesimpulannya secara bersama variabel nilai tukar rupiah dan inflasi memiliki pengaruh positif dan signifikan terhadap profitabilitas Bank Umum Syariah di Indonesia.

1. Dengan adanya beberapa temuan yang cukup menarik pada penelitian, maka diharapkan pihak perbankan sebagai lembaga intermediasi yang juga berpengaruh terhadap kebijakan moneter dapat lebih meningkatkan kinerja keuangannya sehingga meningkatkan kepercayaan dari pihak ketiga maupun stakeholders dan terhindar dari permasalahan likuiditas. Namun perlu diperhatikan lebih juga dalam beberapa hal berikut antara lain 
kebijakan penghimpunan dana dari pihak ketiga, meningkatkan perolehan laba serta lebih waspada terhadap perubahan kebijakan ekonomi makro. Bagi peneliti selanjutnya diharapkan bisa menambahkan faktor-faktor lain sebagai variabel independen yang mempengaruhi profitabilitas Bank Umum Syariah, mengingat nilai tukar rupiah dan inflasi memiliki R Square dari penelitian ini yang masih $11,8 \%$ sehingga peluang penelitian lain akan mengembangkan penelitian lain dengan topik yang sama sekitar $88,2 \%$.

\section{DAFTAR PUSTAKA}

Abimanyu, Yoopi. (2004). Memahami Kurs Valuta Asing. Jakarta: Lembaga Penerbit Fakultas Ekonomi Universitas Indonesia.

Ajdar, Ufiya. (2017). Analisis Pengaruh Makro Ekonomi terhadap Profitabilitas Perbankan Syariah melalui Inflasi sebagai Intervening.

Antonio, Muhammad Syafii. (2011). Bank Syariah dari Teori Ke Praktik. Jakarta: Gema Insani.

Apriyani. (2015). Semester I 21015, Laba Sejumlah Bank Tergerus. Jakarta: infobanknews.com.

Ascarya. (2011). Akad dan Produk Bank Syariah. Jakarta: PT Raja Grafindo Persada.

Dendawijaya, Lukman. (2005). Manajemen Perbankan, Edisi Kedua. Bogor: Ghalia Indonesia.

Fauzie, Aji. (2017). Tantangan Perbankan Syariah di 2017. Yogyakarta: www.kompasiana.com.

Gampito. (2013). Ekonomi Makro Islam (Suatu Pengantar). Batusangkar: STAIN Batusangkar Press.

Hidayati, Amalia Nuril. (2014). Pengaruh Inflasi, BI Rate dan Kurs Terhadap Profitabilitas Bank Umum Syariah di Indonesia. AN-NISBAH, Vol. 01, No. 01, Oktober 2014.

Hossain, Akhand Akhtar. (2010). Bank Sentral dan Kebijakan Moneter di Asia Pasifik. Jakarta: PT RajaGrafindo Persada.

Husein, Umar. (2010). Riset Pemasaran dan Bisnis. Jakarta: Gramedia Pustaka Utama.

Iska, Syukri. (2012). Sistem Perbankan Syariah di Indonesia dalam Perspektif fikih Ekonomi. Yogyakarta: Fajar Media Press.

Kamus Besar Bahasa Indonesia (KBBI). 2017.

Karim, Adiwarman A. (2011). Ekonomi Makro Islami. Jakarta: Rajawali Press.

Kasmir. (2011). Analisis Laporan Keuangan. Jakarta: Grafindo Persada.

Latifah, Leilia Nur. (2016). Pengaruh Variabel Makro Ekonomi terhadap Profitabilitas Bank Umum Syariah di Indonesia periode 2011-2015.

Muhammad. (2005). Manajemen Bank Syariah. Yogyakarta: UPP AMP YKPN.

Pohan, Aulia. (2008). Potret Kebijakan Moneter Indonesia. Jakarta: PT. Raja Grafindo Persada.

Prawironegoro, Darsono. (2014). Manajemen Keuangan . Jakarta: Mitra Wacana Media.

Pristyadi, Nur Laili. (2013). Teori Ekonomi. Yogyakarta: Graha Ilmu.

Rachman, Taufik. (2011). Perbankan Syariah Tahan Banting Hadapi Krisis Global. Jakarta: Republika.co.id.

Rivai Veithzal, dkk. (2007). Bank and Institution Financial Management Conventional dan Sharia System. Jakarta: PT. Raja Grafindo Persada. 
Rizal Yaya, dkk. (2009). Akuntansi Perbankan Syariah Teori dan Praktik Kontemporer. Jakarta: Salemba Empat.

Rizal, S. I. (2005). Lembaga Keuangan Syariah. Batusangkar: STAIN Batusangkar.

Rozalinda. (2014). Ekonomi Islam Teori dan Aplikasinya pada Aktifitas Ekonomi. Jakarta: Rajawali Press.

Santosa, Budi. (2009). Hubungan variabel makro ekonomi terhadap kinerja keuangan pada PT. Bank Syariah Mandiri.

Sudarsono, Heri. (2008). Bank dan Lembaga Keuangan Syariah. Yogyakarta: Ekosiana.

Sugiyono. (2012). Memahami Penelitian Kualitatif. Bandung: Alfabeta.

Ulfah, Rizkia. (2011). Pengaruh Makroekonomi (inflasi, BI rate dan Nilai Tukar) terhadap Penetapan Nisbah Bagi Hasil Deposito Muḍārabah Perbankan Syariah di Indonesia (periode Januari 2006-Desember 2010.

Winarto, Andi. (2015, 06). Faktor-Faktor yang mempengaruhi Tingkat Suku Bunga. Retrieved Maret 14, 2018, from http://definisipengertian.com/2015/06/pengertian-teori-tingkat-suku-bunga.html

Wirdyaningsih. (2005). Bank dan Asuransi Islam di Indonesia . Jakarta: Kencana Prenada Media.

Wiroso. (2005). Penghimpunan Dana dan Distribusi Hasil Usaha Bank Syariah. Jakarta: PT. Grasindo

www.bi.go.id. (2018). Sekilas Perbankan Syariah di Indonesia. Jakarta: Bank Indonesia. www.ojk.go.id. Sejarah Berdirinya Bank Syariah. Jakarta: Otoritas Jasa Keuangan 